\title{
On "Bringing on the Menses": The Criminal Liability of Women and the Therapeutic Exception in Canadian Abortion Law
}

Shelley A. M. Gavigan

Osgoode Hall Law School of York University, sgavigan@osgoode.yorku.ca

Source Publication:

Canadian Journal of Women and the Law. Volume 1, Number 2 (1986), p. 279-312.

Follow this and additional works at: https://digitalcommons.osgoode.yorku.ca/scholarly_works (c) $(i) \Theta(9$

This work is licensed under a Creative Commons Attribution-Noncommercial-No Derivative Works 4.0 License.

\section{Recommended Citation}

Gavigan, Shelley A. M. "On "Bringinging on the Menses": The Criminal Liability of Women and the Therapeutic Exception in Canadian Abortion Law." Canadian Journal of Women and the Law 1.2 (1986): 279-312. 
Osgoode Legal Studies Research Paper No. 15

Vol. 13/ Issue. 3/ (2017)

\title{
On "Bringing on the Menses": The Criminal Liability of Women and the Therapeutic Exception in Canadian Abortion Law \\ Canadian Journal of Women and the Law, Vol.1(2), 1986.
}

\author{
Shelly A. M. Gavigan
}

\begin{abstract}
:
La philosophe du droit et la science juridique ont longtemps passé sous silence la question de la responsabilité criminelle des femmes cherchant à se faire avorter dans le cadre du droit pénal anglo-canadien. L'auteure étudie l'aspect criminel de l'avortement et les conséquences de son interdiction. Elle analyse l'évolution historique de la pratique de l'avortement pour raisons thérapeutiques, ainsi que la législation qui en résulte. En faisant appel aux travaux des historiens et des sociologues qui se sont penchés sur l'avortement et la contraception, elle explore les implications d'une telle politique pour les femmes qui désirent mettre fin à leur grossesse. Elle met un relief la signification sociale du droit et des pratiques médicales dans ce domaine. Elle affirme que les juristes féministes se doivent de prendre en compte la résistance et les luttes des femmes.
\end{abstract}

\section{Author(s):}

Shelly A. M. Gavigan

Osgoode Hall Law School, York University

E: sgavigan@osgoode.yorku.ca 


\title{
On "Brimging on the Menses": The Crimimal Liabillity of Wormen and the Therapeutic Exception in Canadian Abortion Law
}

\author{
- 1986 by Shelley A.M. Gavigan
}

La philosophie du droit et la science juridique ont longtemps passé sous silence la question de la responsabilité criminelle des femmes cherchant à se faire avorter dans le cadre du droit pénal anglo-canadien. L'auteure étudie l'aspect criminel de l'avortement et les conséquences de son interdiction. Elle analyse l'évolution historique de la pratique de l'avortement pour raisons thérapeutiques, ainsi que la légalisation qui en résulte. En faisant appel aux travaux des bistoriens et des sociologues qui se sont penchés sur l'avortement et la contraception, elle explore les implications d'une telle politique pour les fermmes qui désirent mettre fin à leur grossesse. Elle met en relief la signification sociale du droit et des pratiques médicales dans ce domaine. Elle affirme que les juristes féministes se doivent de prendre en compte la résistance et les luttes des femmes.

\section{Women and Abortion: Setting the Scene}

In the last fifteen years, restrictive abortion laws have increasingly been the site of determined feminist struggle; nowhere is this more true than in Canada, where the women's movement's current campaign of support for free-standing abortion clinics has witnessed the equally determined response of the state to prosecute those who have the temerity to challenge the therapeutic abortion provisions of the Canadian Criminal Code. It is a telling comment upon Canadian politics that the anachronistic requirement of therapeutic abortion committees represents the only compromise the Canadian state has been able to muster in response to opposing demands for repeal or further criminalization.

In the midst of important political and legal struggles, one is often denied the luxury of reflecting on and analyzing fundamental issues. Thus it is to the good that in the current context, feminists still recognize the need to reexamine the 
significance of abortion in women's lives. ${ }^{1}$ Although the abortion law has been the site of struggle in recent years, what has occasionally been lost sight of is the historical, prefeminist struggle of women to control their fertility. Important as the law is, it has never been determinative or definitive of women's response to pregnancy or of their desire for fertility and birth control. As Rosalind Petchesky has observed: "The remarkable thing is not that those in power have attempted to control population by controlling the fertility of women but that they have been so unsuccessful."2 She contends that they have been so unsuccessful because of everyday practices of ordinary women in having or not having children according to their own sense of needs. In this view, "abortion has been the mean to which women have resorted with greatest persistence over time."3 Other feminists have argued forcefully that abortion is essentially "violence" involving the "issue of forced sex": "Abortion is violence: a deep desperate violence inflicted by a woman upon, first of all herself. It is the offspring and will continue to be the accuser, of a more pervasive and prevalent violence, the violence of rapism." While this emphasis undoubtedly brings to the fore the continued substantive inequality of women in the context of male domination, I would argue that it tends to diminish the historical importance of abortion to women, as an active response to unwanted pregnancy, an affirmation of their autonomy, and an indication of moments of empowerment. This is not at all to romanticize abortion nor to argue that is to be celebrated as the quintessence of women's experience, but rather to insist that women have not been complicit or passive in their subordination in different contexts. More productive to developing an adequate understanding of abortion to women is Rosalind Petchesky's argument that women "choose" to have abortions under an enormous range of conditions, "some of which are oppressive, desperate, or even dehumanized." However, she emphasizes that "in most cases they do so consciously, as active agents of their fertility and not merely victims of their biology or pawns of 'natural' forces like population movements."

In this article, I examine the historical development of the criminal liability of women seeking to obtain or self-induce abortions within the general abortion prohibition in Canada. I argue that the development of medical technology which may bring with it safe methods of self-induced abortion and menstrual regulation ought not to be regarded with complete suspicion and apprehension. Without succumbing to the illusion that this issue is wholly determined by either law or

1. See, for example, Kathleen McDonnell, Not an Easy Choice (Toronto: Women's Press, 1984); Adrienne Rich, Of Woman Born: Motherbood as Experience and Institution (New York: W. W. Norton, 1976); Catharine A. MacKinnon, "The Male Ideology of Privacy: A Feminist Perspective on the Right to Abortion," Radical America 17 (1983): 23; Carol Gilligan, In a Different Voice (Cambridge: Harvard University Press, 1982); Rosalind Petchesky, Abortion and Woman's Choice: The State, Sexuality, and Reproductive Freedom (Boston: Northeastern University Press, 1985).

2. Petchesky, Abortion and Woman's Choice, 26.

. Ibid.

Rich, Of Woman Born, 274.

5. MacKinnon, "The Male Ideology of Privacy," 26.

6. Rich, Of Woman Born, 274.

7. Petchesky, Abortion and Woman's Choice, 27.

8. Ibid. medicine, I hope to be able to illustrate that creative challenges to the law are on the horizon, challenges even more exciting when one considers the historically documented struggle of women to control their fertility and their resistance to the law.

\section{Medical and Legal Issues}

Menstrual regulation that is both medically safe and easily accessible offers women the possibility of acquiring a degree of autonomy and freedom in relation to their reproductive capacities that has been previously unavailable. Menstrual regulation technology may render the criminal prohibition of abortion anachronistic. The legal developments relating to abortion in this century have focused on the extent to which a therapeutic abortion is to be permitted. The few reported cases in England and Canada address the importance of the bona fide conduct of the medical practitioner in the determination that the abortion is necessary. ${ }^{9}$ The extent to which the medical practitioner must be personally or intimately involved throughout the procedure has been the subject of recent litigation in England. ${ }^{10}$ As with any hospital procedure, there can be no question but that the doctor is in charge. The "great social responsibility" in matters of abortion now rests almost exclusively with the medical profession. ${ }^{11}$ And yet, abortion is a health care procedure unlike most in medical practice: "Abortion is usually a voluntary process. Much of the need for it is in the mind of the woman who requests it. More than any other operation, the decision to go through with it is in the hands of the patient." 2 An English doctor has observed: "By the time she comes to see me, a woman has usually worked out why she wants an abortion. I just need to see that she has some knowledge of the alternatives... But I do think it is humiliating and degrading for a woman to have to come in here and exaggerate her distress, or convince me that she wants an abortion." 13 Put more forcefully, women who seek abortions challenge the traditional doctorpatient relationship: they have decided for themselves what needs to be done they have self-diagnosed. ${ }^{14}$ This is a fact of life which the fields of law and medicine have been loathe to acknowledge, much less countenance.

Technological advances, both recent and imminent, have greater or less significance in different contexts: "the 'right to choose' means very little when

9. See, for example, R. v. Bourne, [1938] 3 All E.R. 615 (K.B.); R. v. Bergmann and Ferguson, unreported, May 1948, Central Criminal Court, referred to in Glanville Williams, "The Law of (C.A.); Morcentaler v. The Quen (1975), 30 C R N.S. 209 (S.C.C.); R. v. MGo [1974] 1 All E.R. 376 C.R.N.S 244 (Que C A.).

.Royal College of $\mathrm{N}$.A.

Royal College of Nurses of the United Kingdom v. Department of Health and Social Security, [1981] 1 All E.R. 545 (H.L.)

11. Paraphrasing Lord Scarman in R. v. Smith (John), [1974] 1 All E.R., 378.

12. Keith Hindell and Madeleine Simms, Abortion Law Reformed (London: Peter Owen, 1971), 16

. Peter Diggory, quoted by Victoria Greenwood and Jock Young, Abortion in Demand (London Pluto Press, 1976), 49

14. Greenwood and Young, Abortion in Demand, 30; Elizabeth Wilson, Women and the Welfare State (London: Tavistock, 1977), 181-182; Michèle Barrett and Helen Roberts, "Doctors and Their Control, ed. Carol Smart and Barry Smart, (London: Routledge and Kegan Paul, 1978): $41,51$. 
women are powerless." 15 The issues relating to fertility control, and in particular abortion legislation, are not determined or resolved primarily by technology; they are political issues. ${ }^{16}$ Nevertheless, within the context of late twentieth century Canada, the development of a means of medically safe and self-administered menstrual regulation as a method of post-coital birth control may contribute to the realization of this basic feminist demand: the right to choose. It is precisely what women have been struggling for in their individual lives since the inception of the statutory prohibition of abortion. And it is precisely this legal issue which has never been directly addressed or clarified as abortion law has developed and been applied over the centuries.

The early self-induced miscarriage or early induction of menstruation may appear to be of little consequence in law: the case law on the point is negligible. Section 251(2) of the Criminal $\operatorname{Code}^{17}$ has never been the subject of judicial interpretation. And yet, this section may become pivotal, and witness the most profound challenge to the criminal prohibition of abortion. ${ }^{18}$ We appear to be at the threshold of medical developments which promise to obviate in practice the intervention of a medical practitioner and facilitate the autonomous determination by a woman as to whether a pregnancy will develop or be allowed to continue - a decision which may be made before an ovum, if fertilized, is even able to implant itself in the uterine wall

The issue of the criminal liability of women who use methods of birth control which operate post-coitally appears to be more significant in the current 'context than the issue of the pregnant woman who attempts to procure her own miscarriage. It remains to be determined whether the Canadian criminal law relating to abortion will pose a threat to women who seek to control their fertility either by means of self-administered methods of menstrual regulation or by postcoital contraception.

There is a rapidly developing body of literature which addresses and examines the medico-legal implications of an equally rapidly developing medical technology. ${ }^{19}$ With respect to post-coital contraception, it has been suggested that

15. Rosalind Petchesky, "Reproductive Freedom: Beyond 'A Woman's Right to Choose'," in Women: Sex and Sexuality, ed. Catharine R. Stimpson and Ethel Spector Person (Chicago: University of Chicago Press, 1980): 92, 95

16. Petchesky, "Reproductive Freedom," 93.

17. R.S.C. 1970 , c. C-34.

18. I am indebted in this argument to Bernard M. Dickens, Medico-Legal Aspects of Family Law (Toronto: Butterworths, 1979), 40-41.

19. See, for example, Victor Tunkel, "Modern Anti-Pregnancy Techniques and the Criminal Law," Criminal Law Review (1974): 461; Anne-Marie Dourlen-Rollier, "Legal Problems Related to Abortion and Menstrual Regulation," Columbia Human Rights Law Review 7 (1975): 120; Luke Lee and John Paxman, "Legal Aspects of Menstrual Regulation: Some Preliminary Observations," Journal of Family Law 14 (1975): 181; Mostyn Embrey, "Developments in Medical Technologies for Fertility Regulation and Their Implications for Medical Legislation," and Victor Tunkel, "The Law Against Family Planning: A Commonwealth Survey," in Three Studies of Abortion Laws in the Commonwealth (London: Commonwealth Secretariat, 1977); Pouru Bhiwandiwala, Rebecca Cook, Bernard Dickens, and Malcolm Potts, "Menstrual Therapies in Commonwealth Asian Law," International Journal of Gynaecology and Obstetrics 20 (1982):273; Rebecca Cook and Bernard Dickens, Emerging Issues in Commonwealth Abortion Laws, 1982 (London: Commonwealth Secretariat, 1983): Diana Brahams, "The Morning-After Pill: Contraception or Abortion," New Law Journal 133 (1983): 417 . any method of birth control which operates after the moment.of fertilization is in essence an abortifacient and offends existing English abortion legislation ${ }^{20}$ Others tend to the view that the law need not be so narrowly construed ${ }^{21}$ and indeed may even accommodate (depending upon the wording of the relevant legislation) some of these medical developments. ${ }^{22}$ It is fairly clear that anything which is administered with the intention of terminating an already diagnosed pregnancy must conform to the legislative requirements respecting abortion. With respect to a pregnancy not yet confirmed, a medical practitioner or other person will still be liable under the abortion law if her or his intent is to induce a miscarriage; the relevant Canadian ${ }^{23}$ and English ${ }^{24}$ legislation makes it an offence for any person to use any means with intent to procure a miscarriage whether or not a woman is pregnant.

However, when a woman acts alone, the prohibition is expressed in different terms. Section 251(2) of the Criminal Code appears to apply only to women who are actually pregnant. ${ }^{25}$ On its face, this subsection appears to offer immunity to a nonpregnant woman who acts alone. Thus the legal question is whether such a woman may lawfully act to intercept a pregnancy before she is in a position to confirm that she is or is not pregnant: Does she risk criminal liability for attempting to do what may be impossible - attempt to procure a miscarriage when she is not pregnant? Is it possible to treat an attempt to induce a menstrua period before pregnancy has been diagnosed as an attempt to cause an abortion? Does the fact of impossibility render her liable to or immune from prosecution under section 251(2)? In short, in spite of the apparently clear wording of section $251(2)$, can a nonpregnant woman be convicted for an attempt to induce a miscarriage when she is not actually pregnant?

\section{The Social Significance of Law}

Any analysis of the relationship between women and the criminal law must acknowledge and examine the specific history of and changes to the legal prohibition of abortion. However, to examine only the legal form and the handful of reported cases offers us little in the way of real understanding of the social meaning of law, whether it is enforced or not. Contraception and abortion illustrate that it is incorrect to perceive women of the past (and, I would argue, women of the present) as the passive victims of legal and medical control. ${ }^{26}$

20. Tunkel, "Modern Anti-Pregnancy Techniques." See also J.C. Smith and Brian Hogan, Criminal Law (London: Butterworths, 1978), 342.

21. Lee and Paxman, "Menstrual Regulation," 206-209; Brahams, "The Morning-After Pill."

. Embrey, "Developments in Medical Technologies"; Bhiwandiwala et al., "Menstrual Therapies" Cook and Dickens, "Emerging Issues," 68. For instance, it is important to note that abortion legislation derived form the Indian Penal Code only prohibits the action of an individual who attempts to procure the abortion of a woman "with child."

23. Criminal Code, R.S.C. 1970 , c. C-34, s.251.

24. Abortion Act, 1967, c. 87 (U.K.)

25. Section 251(2) of the Criminal Code, R.S.C. 1970, c. C-34, provides: "Every female person who, being pregnant, with intent to procure her own miscarriage, uses any means or permits any menns to be used for the purpose of carrying out her intention is guilty of an indictable offence and liable to imprisonment for two years."

26. See also Petchesky, "Reproductive Freedom," 107. 
It is important to appreciate the extent to which women have continued to control their own fertility despite the extension of the criminal sanction over the entire period of pregnancy and the increased involvement of the medical profession in fertility control. This forms a critical historical backdrop against which we may be better able to understand why women respond so enthusiastically to new methods of abortion and contraception which are simpler and more accessible. ${ }^{27}$ Resistance to the criminal prohibition - in particular the form of this resistance by means of self-induction of abortion - illustrates an active response to an unwanted pregnancy or possibility of pregnancy, as well as a willingness to endure pain to obtain and exercise that measure of control.

The failure or refusal to understand the significance of abortion in the lives of women flaws much of the legal historical work relating to the history of abortion law and abortion technology. Paradoxically, two legal historians of otherwise opposing interpretations ${ }^{28}$ share a common weakness: their analysis is directed exclusively at the legal form. Cyril C. Means Jr. argues that until 1803, English women enjoyed a common law liberty (presumably, as opposed to a common law "right") of abortion which was usurped by Lord Ellenborough's Act. ${ }^{29}$ In advancing this interesting argument, he ignores absolutely the formal and substantive inequality of women's lives in eighteenth century England. Joseph Dellapenna effectively denies that women ever had any real interest in controlling their fertility, let alone any right or liberty to do so. His work constitutes an affront to the lives and experiences of the women of the historical period he examines; that women are essentially invisible in an analysis of law which so directly affected them renders his work of limited usefulness

The crux of my argument is that the history of restrictive abortion legislation is also the history of women's resistance to it; but I do not mean to suggest by this that the criminal sanction is or has been of little consequence to women. The criminalization of abortion in Anglo-Canadian law has had at the very least a profound negative effect on research into safe methods of abortion. As even Joseph Dellapenna is forced to concede, the illegality of abortion "probably slowed the perfection of new abortion techniques." Given that repressive

27. Recent studies on methods of abortion and menstrual regulation report that although vacuum aspiration is quick and next to painless, women prefer self-administered pharmacological methods days. One study attributed this preference to the pereived no during One study atributed this preference to the perceived naturalness of the method, privacy during teatment and, potentally, the decision to abort; see Ann-Sofie Rosen, Lars Nystedt, Marc Bygdeman, and " ca Lundstrom, "Acceptability of a Nonsurgical Method to Terminate Very Early Pregnancy," Contraception 19 (1979): 107, 108; see also Livia Wan, Andrew Stiber, and Juana Tunkel, "Termination of Very Early Pregnancy by Vaginal Suppositories - (15S)-15-Methy Prostaglandin F $\mathrm{F}_{2}$ Alpha Methyl Ester," Contraception 24 (1981): 603, 613; Marc Bygdeman, J.J. Christiansen, R. Green, and S. Zheng, "Self-Administration of Prostaglandin for Termination of Early Pregnancy," Contraception 24 (1981): 45

28. Cyril C. Means Jr., "The Phoenix of Abortional Freedom: Is a Penumbral or Ninth-Amendmen Right About to Arise from the Nineteenth-Century Ashes of A Fourteenth Century Common-Law Liberty?" New York Law Forum 17 (1971): 335; Joseph Dellapenna, "The History of Abortion Technology, Morality and Law," University of Pittsburgh Law Review 40 (1979): 359.

29. $1803,43 \mathrm{Geo}$. II, c. 58

30. Joseph Dellapenna, "The History of Abortion," 413. See also Lee and Paxman, "Menstrual Regulation," $190-92$. measures designed to eradicate the practice of abortion have never been successful, it is necessary to consider the significance of the retention of the prohibition to women's lives. To begin to do this involves an examination of the ways in which the law and the state have been conceptualized in feminis critiques of law.

Janet Rifkin has begun to explore the relationship between law and patriarchy from a perspective which empasizes the role played by law and legal ideology in perpetuating male domination of women. ${ }^{31}$ She defines "patriarchy" as "any kind of group organization in which males hold dominant power and determine what parts females shall and shall not play...." In In her analysis, law is powerful both as a symbol of male authority and as a vehicle of male authority: "This power is based both on an ideology of law and ideology of women which is supported by law. One function of ideology is to mystify social reality and to block social change." 33 Thus she accepts an analysis of the early feminist suffragists which asserts that in struggling for equal rights, such as the vote, the early feminists did not challenge the ideology of law; rather, she argues, "they perpetuated mystifications of law which supported the status quo." ${ }^{34}$ This is indeed a difficult, if not an untenable, argument for a feminist lawyer to advance, given that women's access to the legal profession only came about through the agitation and struggle of these same feminist suffragists. Full citizenship rights for women today may be considered to be part of the status quo, but it is difficult to understand how, in the context of the late nineteenth or early twentieth centuries, the demand for suffrage may be so characterized. It is a tremendous contradiction for feminist scholarship to be so dismissive of the first wave of feminist struggle. ${ }^{35}$

More productive to ongoing feminist attempts to understand the relationship of the law to the subordination of women is Carol Smart's suggestion that feminists should examine how the role of law is produced under a capitalist order, and how law modifies, reinforces, and undermines patriarchal relations. ${ }^{36}$ To observe, for example, that women have not achieved real equality despite the successful struggle for the vote does not necessarily lead one to conclude that the concept of formal equality is only a mystification or a sham. As Juliet Mitchell has argued, attaining the vote was, at the very least, "itself a certain progress, which can help make possible a further advance." ${ }^{37}$ It seems that for Janet Rifkin the

31. Janet Rifkin, "Toward a Theory of Law and Patriarchy," Harvard Women and Law Journal 3 (1980): 83

32. Ibid. This definition is also used in M.D.A. Freeman, "Legal Systems, Patriarchal Ideologies and Domestic Violence: A Case Study of the English Legal System," in Research in Law, Deviance and Social Control: A Research Annual, ed. Stephen Spitzer and Rita J. Simon 4 (London: JAI Press, 1982), 131.

33. Rifkin, "Law and Patriarchy," 84

34. Ibid., 87.

35. See also Carol Smart, "Law and the Control of Women's Sexuality: The Case of the 1950s," in Controlling Women: The Normal and the Deviant, ed. Bridget Hutter and Gillian Willins (London: Croom Helm, 1981): 40; 42-43; Veronica Beechey, "Women and Production: A Critical Analysis of Sociological Theories of Women's Work," in Feminism and Materialism Kuhn and Annomerie Wolpe (London: Routledge and Feminism and Materialism, ed. Annette 36. Smart, "Women's Sexuality," 42.

37. Juliet Mitchell, Woman's Estate (Middlesex: Penguin Books, 1971), 113. 
form of law and formal equality is not problematic because it is always and everywhere the ultimate symbol of male authority. This perspective seriously limits one's ability to analyse and understand the different forms and contexts of law and their contribution to the subordination of women. As E. P. Thompson has argued: "If we suppose that law is no more than a mystifying and pompous way in which class [or male] power is registered, then we need not waste our labour in studying its forms. One Act would be much the same as another and all from the the standpoint of the ruled, would be Black. It is because law matters that we have bothered with this story at all.",38

There is yet another theme in some feminist scholarship in the area of law which is troubling. In Janet Rifkin's work it is the definition of patriarchy as determinative of women's lives. A similar approach characterizes Susan Edwards' work. ${ }^{39}$ Her subject is the interrelationship of medico-legal discourse as it has constructed and produced female sexuality in the sex laws. She sets out in great detail the male medico-legal conspiracy, in which women consistently emerge as passive victims, trebly so: as victims of male exploitation in sexual offences, as victims of the on medical practitioners, and as victims of sex-bound laws. From her work, one derives no sense that women have ever exercised any power or been active in any way in response to the law. And while her focus is admittedly on the implications of the criminal law and medical practice as it primarily affects women as victims, it may not be a conclusive image that is presented. As I attempt to illustrate in this article, despite the profound influence of the medical profession and the criminal law over abortion from the earliest years of the nineteenth century, it is clear that this influence has not been ipso facto determinative of the course that women who seek to terminate an unwanted pregnancy have followed.

In this respect then, I argue that feminist legal scholarship might well benefit from the kind of consciousness that has begun to characterize feminist historical work on women. As United States feminist historian Gerda Lerner has argued "The true history of women is the history of their ongoing functioning in [the] male-defined world, on their own terms." 40 I do not suggest that the concept of oppression is irrelevant to the examination of the law and women; I am suggesting that legal definitions and prohibitions do not tell us everything we need to know in this study: law is only one part of the story.

38. E.P. Thompson, Whigs and Hunters: The Origins of the Black Act (Middlesex: Penguin Books, 1975), 267-68.

39. Susan Edwards, Female Sexuality and the Law (Oxford: Martin Robertson, 1981).
40. "Placing Women in History: A 1975 Perspective," in Liberating Women's History, ed. Bernice A. Carroll (Urbana: University of Illinois Press, 1976): 357, 358-59. See also Judith Newton, Mary Ryan, and Judith Walkowitz, "Editors' Introduction," in Sex and Class in Women's History, ed. Judith Newton, Mary Ryan, and Judith Walkowitz (Iondon: Routledge and Kegan Paw1, 1983): 1-2: "After half a decade of research ...we have moved beyond a one dimensional emphasis upon oppression and victimization of women and have also come to recognize and explore the lines along which women have shaped their own history and that of mn" " and explore the lines recent which Feminist History Group, The Semal Domamics of Histome (London: Pluto Press, 1983).

\section{The Liability of Women Under Abortion Law \\ English Criminal Law}

It is difficult to discern with a great deal of confidence the position at common law of a woman who sought out someone to assist her in the matter of attempting to procure her own abortion, or indeed the woman who attempted to procure her own. ${ }^{41}$ Because the common law only prohibited abortions after quickening, the consistent and logical position would have been that anything that was attempted before quickening would not have been the subject of criminal prosecution. The few reported common law cases are unclear on these points.

In Margaret Tinckler's Case, ${ }^{42}$ the defence lawyer sought to have the deceased pregnant woman's dying statement excluded on the ground that she was particeps criminis because she had sought the abortion herself, and her evidence therefore required corroboration. While the judges were divided on this issue, a majority held that her dying declarations were not to be considered as coming from a particeps criminis because she considered herself to be dying at the time she made them; therefore she had no interest to serve in excusing herself or in unjustly accusing another. ${ }^{43}$

In a later case, $R$. v. Wilson, ${ }^{44}$ in which the woman had not died as a result of the abortion attempt, the accused was charged under the Offences Against the Person $\mathrm{Act}^{45}$ with unlawfully administering and causing to be taken by a pregnant woman certain poison with intent to procure her miscarriage. The case had been tried before Coleridge J. at the Spring Assizes in Hertford in 1856. Although the accused was not represented by counsel, it appears that someone raised on her behalf the argument that because she was not present when the substance was taken, she could not be said to have administered it, but simply had provided the woman with the means to take it herself. ${ }^{46}$ The following exchange between two of the judges suggests that they are uncertain about the relative liabilities of the woman who took the drug and the woman who supplied it to her for the purpose of procuring her miscarriage:

Jervis C.J.: He who does an act by means of an innocent agent commits the act himself May it not be said that the woman was an innocent agent? She committed no offence against the law.

41. Bernard Dickens, Abortion and the Law (Bristol: Macgibbon and Kee, 1966), 24, suggests that the woman who procured her own miscartiage was herself guilty of a common law misdemeanour. 42. This 1790 case is cited and discussed at length in Edward Hyde East, $A$ Treatise of the Pleas of the Crown 1 (London: A. Strahan, 1803), 230, 354-58. Edward East's discussion of the case is reproduced in full in Means, "Abortional Freedom," 363-67.

43. East, Pleas of the Crown, 355-58.

44. (1856), Dears \& Bell 127; 169 E.R. 945 (C.C.A.)

45. $1837,7 \mathrm{Wm}$. IV \& 1 Vict., c. 85 , section 6 .

46. R. v. Wilson, 169 E.R., 946 
Coleridge J.: Not innocent. She is guilty of a misdemeanour, but not of the statutable felony. ${ }^{4}$

This passage suggests that Jervis C.J. was prepared to interpret the phrase "innocent agent" as encompassing a wider category of persons than was usually understood to be covered. ${ }^{48}$

In an earlier case, $R$. v. Russell, ${ }^{49}$ the prosecutor had suggested in the course of his argument:

Prosecutor: Independent of that statute [Lord Ellenborough's Act, 1803], it was a misdemeanour at common law in a woman to take any substance with intent to procure abortion.

Lord Tenterden, C.J.: Is there any authority for it?

Prosecutor: No; but the act itself is one, having in it all the ingredients of a crime. It is against the law of God, injurious to the individual, and prejudicial to the state. ${ }^{50}$

It is significant that neither of these passages mention the question of quickening Nevertheless, they do offer some shaky support for the proposition that a woman who took a noxious substance with the intent to procure her own abortion may have been guilty of a misdemeanour at common law. However, I would argue that this could have happened only in cases in which the woman was beyond the point of quickening in her pregnancy.

James Mohr $r^{51}$ has suggested that the target of the first wave of restrictive abortion legislation - enacted in Great Britain and the United States in the first half of the nineteenth century - was the person who performed the abortion or administered the abortifacient rather that the woman herself. It is his view that the earliest abortion prohibitions emerged "from the struggles of both legislators and physicians to control medical practice" ${ }^{\prime 52}$ and were therefore directed at

47. Ibid

48. A child of tender years, a madman, or someone of defective mind incited to commit an offence was an innocent agent, and the inciter was the principal. This rule also applied to the "transmission of poison by the hands of a person of any age who is ignorant of its nature and the purpose for which he is to deliver it...." J.W. Cecil Turner, ed., Russell on Crime (London: Stevens and Sons, 1964), 129-130. Elsewhere he simply described an innocent agent as one with "no blamable intentions." J.W. Cecil, ed., Kenny's Outlines of Criminal Law (Cambridge University Press, 1958), 97.

49. (1832), 1 Mood. 356, 168 E.R. 1302. I am indebted to Constance B. Backhouse for this reference.

50. 168 E.R., 1305

51. James Mohr, Abortion in America (New York: Oxford University Press, 1978), 43. He identifes the years 1821 to 1841 as witnessing the first wave of abortion legislation in the United States. Ibid., $20-45$.

52. Mohr, Abortion in America, 43. regulating the practice of medicine rather than at discouraging women from seeking abortions. In marshalling his evidence and advancing his Mohr relies very heavily on the absence of any express reference in the early legislation to the liability of women who sought or self-induced abortion. Constance Backhouse ${ }^{53}$ has examined the state of the law in nineteenth century. Canada in this respect, and has found some support for James Moteenth century the Canadian context.

Despite the statutory silence and acknowledged ambiguity of the earliest English legislation, the absence of any express reference to a woman's liability does not ipso facto support the conclusion that she was free from criminal liability. ${ }^{54}$ James Mohr's interpretation may derive largely from the fact that prior to 1861 in England, abortion legislation made no express reference to the liability of the woman herself. Before 1861, the prohibitions referred to "any person, with intent to procure the miscarriage of any woman." 55 The first amendments to the abortion prohibition, enacted in 1837 , referred to "whosoever, with intent to procure the miscarriage of any woman." reference to pregnant women: "Every woman, being with child, who, with intent to procure her own miscarriage....and whosoever with intent to procure the miscarriage of any woman." 57

There is scant case law on the question of the pregnant woman's liability, ${ }^{58}$ and only the odd comment in obiter suggests that the woman herself was not guilty of the statutory felony. ${ }^{59}$ Leaving aside for the moment the issue of the liability of a woman as a principal in the second degree or as an accessory before the fact to the felony of another, ${ }^{60}$ there may be some support in the case of $R$. v. $R u s s e l l^{61}$ for the proposition that a woman who attempted to induce her own. miscatriage was guilty of the trial of was a married was a married man and keeper of the gaol for the county of Huntingdon. ${ }^{62}$ The deceased woman, Sarah Wormsley, had been his servant until shortly before her death from arsenic poisoning. Henry Russell had provided her with the arsenic. In a statement taken from her under oath just before she died, she indicated that she had "had conexxion [sic] with" Mr. Russell several times, and was now with child, although she had not felt tine child move. ${ }^{63}$ From the case report it appears that she was about four months pregnant at the time of her death. In her

53. Constance Backhouse, "Involuntary Motherhood: Abortion, Birth Control and the Law in Nineteenth Century Canada," Windsor Yearbook of Access to Justice 3 (1983): 61

54. Dickens, Abortion and the Law, 24-28.

55. Offences Against the Person Act (Lord Lansdowne's Act), 1828, 9 Geo. IV, c. 31, section 13.

56. Offences Against the Person Act, $1837,7 \mathrm{Wm}$. IV \& 1 Vict

57. Offences Against the Person Act, 1861, 24 \&. 25 Vict, c. 100, sect section 6.

58. Backhouse, "Involuntary Act, $1861,24 \& 25$ Vict., c. 100, section 58.

9. R v Wilson "(1856, Dears \& Bell 127, 1693 .

60. See Turner Russell on Crime 132-34; 150 E.R. 945 (C.C.A.)

61. R. v. Russell (1832),

62. This case is reported to have "excited inten. 1302.

of the "respectable station in life which the prterest in the county of Huntingdon" in part because the Huntingdon Assizes

63. 168 E.R., 1303 . 
statement, she said that she did not know how he obtained the arsenic, he did not tell her what effect it would have, and she did not know what it would do: "he told me to take it, and I took it."

Henry Russell was not indicted under Lord Ellenborough's Act; ${ }^{65}$ instead, he was indicted as an accessory before the fact to her constructive suicide. ${ }^{66}$ At the trial, his defence lawyer argued that Lord Ellenborough's act did not apply to a woman who administered medicine to herself for the purpose of procuring her miscarriage. Accordingly, if the woman was guilty of no offence, there was neither a principal nor an accessory. This objection was overruled by the trial judge, Baron Vaughan, and it was not raised again when the case was argued subsequently before the entire panel of judges. ${ }^{67}$ On appeal, the case turned primarily on the interpretation of an 1828 statute which had been enacted to correct a perceived procedural defect in the common law: the requirement that the principal in a criminal offence be convicted before any accessory before the fact could be indicted and convicted. ${ }^{68}$ By virtue of the 1828 statute, this rule was abrogated to allow the prosecution, conviction, and sentencing of an accessory before the fact whether or not the principal was "amenable to justice." trial, the defence lawyer had argued unsuccessfully that the 1828 legislation could not be invoked to convict an accessory before the fact when the case involved a principal who was felo de se. ${ }^{70}$ On appeal, he reiterated that the statute did not "relate to cases where the principal [could] not from the nature of the case ever be tried"71 and he urged upon the judges that there was "no intention shewn in the statute to create any new offence." 72 The judges ruled unanimously that Henry Russell was an accessory before the fact, but they were divided with respect to the issue of his liability; a majority of the judges accepted the argument advanced by his counsel. ${ }^{73}$ The judges were likewise divided with respect to whether Sarah

64. Ibid.
65. $1803,43 \mathrm{Geo} . \mathrm{II}, \mathrm{c} .58$.

66. R. v. Russell (1832), 1 Mood. 356, 168 E.R. 1302. One who committed suicide was felo de se (or felonia de se), a felon in respect of him(her)self, and essentially guilty of "self-murder." Turner, felonia de se), a felon in respect of him(her)self, and essentially guilty of "self-murder." Turner, Russell on Crime, 558. Prior to 1823, the bodies of persons who were felo de se were to be taken to a crossroads and buried (1823, 4 Geo. IV, c. 52). See also Jowitt's Dictionary of English Law (London: Sweet and Maxwell,
1959), s.v. "felo de se."

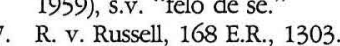

68. For a discussion of the position at common law see Matthew Hale, The History of the Pleas of the Crown 2 (London: Professional Books, 1972 reprint of 1736 ed.), 222-24; William Blackstone, Commentaries on the Laws of England 4 (Oxford: Clarendon Press, 1775), 39-40.

69. An Act for Improving the Administration of Criminal Justice in England, 1828, 7 Geo. IV, c. 64 . The relevant section, section 9, provided: "And for the more effectual prosecution of accessories before the fact to felony; be it enacted, that if any person shall counsel or command any other person to commit any felony, whether the same be a felony at common law, or by virtue of any statute or statutes to be made, the Person so counselling or procuring or commanding shall be deemed guilty of felony, and may be indicted and convicted of a substantive felony whether previously convicted, or shall or shall not be amenable to justice, and may be punished in the same manner as any accessory before the fact to the felony, if convicted as an accessory, may be punished...."

70. 168 E.R., 1304

71. 168 E.R., 1305

72. Ibid

3. 168 E.R., 1306
Wormsley was felo de se by virtue of her death from the taking of the poison for the purpose of procuring her miscarriage; a majority held that she was felo de se..$^{74}$ It would appear from the report that the judges did not consider her assertion in her dying statement - that she did not know what the arsenic would do - to be true. Thus, implicit in the majority (albeit in obiter) decision is the position that a woman who took a poison for the purpose of procuring her miscarriage was herself guilty of the statutory felony. The reasons of the minority are likewise not set out, although one may infer from the case report that Lord Tenterden C.J. was not persuaded by the prosecution's argument in this respect. ${ }^{75}$

When the Offences Against the Person Act was consolidated in $1861,{ }^{76}$ the legislation concerning abortion was again refined. For the first time, the legislation expressly prohibited a pregnant woman from attempting to procure her own miscarriage. The legislation did not expressly mention nonpregnant women, but that silence did not ipso facto bring with it immunity from criminal liability. The reported case law is again limited, but it is significant that cases on point held nonpregnant women to be liable as conspirators, aiders, and abettors under this legislation. In $R$. v. Whitchurch, ${ }^{77}$ the Court of Criminal Appeal affirmed the conviction of a woman for conspiracy to procure her own abortion even though she had not been pregnant. ${ }^{78}$ Of the woman's appeal, Coleridge L.C.J. said: "I cannot entertain the slightest doubt that if three persons combine to commit a felony they are all guilty of conspiracy, although the person on whom the offence was committed, could not, if she stood alone, be guilty of the intended offence." $" 79$

In $R$. v. Sockett, ${ }^{80}$ it was held that the woman herself was an aider and abettor to the offence, without respect to the existence of pregnancy. The judge was not impressed with the legislative distinction between a nonpregnant woman and any other person who attempted to procure her miscarriage. ${ }^{81}$ In $R$. v. Brown ${ }^{82}$ Darling J. made a similar pronouncement with respect to the liability of individual women: "If a woman believing she is taking a noxious thing within the statute, does, with intent to procure abortion, take a thing that is in fact harmless, she is guilty of an attempt to procure abortion within the meaning of the statute." 83 The significance of this dictum may be limited in light of the decision of the House of Lords in Haughton v. Smith. ${ }^{81}$ In any event, as J.C. Smith and Brian Hogan have suggested, Darling J. directed himself to the wrong question, for the charge was

74. Ibid.

75. 168 E.R. 1302 As for Henry Russell, it would appear that he chose to leave the country (presumably in disgrace) following his acquittal rather than risk facing an indictment chatring him with the abortion felony proper.

76. Offences Against the Person Act, 1861, 24 \& 25 Vict., c. 100, section 58

77. (1890), 24 Q.B.D. 420 (C.C.A.).

78. Her two associates, who were clearly caught by the second part of section 58 of the Offences Against the Person Act whether or not she was pregnant, did not appeal.

79. 24 Q.B.D., 422.

80. (1907-08), 24 T.L.R. 893 (C.C.A.)

81. In the words of Alverstone L.C.J., "it is not easy to see why the two offences differ in one essential particular." 24 T.L.R., 894

82. (1899), $63 \mathrm{~J}$

84. [1973] 3 All E.R. 1109 (H.L.). 
not one of attempting to procure abortion but of attempting to administer a noxious thing. As they point out, the women did intend to administer a noxious thing, but there was a failure of intention because they administered only a harmless thing. ${ }^{85}$

Glanville Williams has specifically criticized the Whitchurch ${ }^{86}$ and Sockett ${ }^{87}$ decisions for eroding the "limitation upon responsibility imposed by Parliament." 88 It is his view that the wording of section 58 of the Offences Against the Person $\mathrm{Act}^{89}$ offered the nonpregnant woman absolute immunity from criminal prosecution. However, it is important to remember that nonpregnant women themselves fall into two categories: those who, believing in error that they are pregnant, draw in another person to assist them in the matter of abortion, and those who, acting alone, take matters into their own hands. Brian Hogan has argued that the preferable and most consistent interpretation of section 58 is that immunity applies only to a nonpregnant woman as a principal in the first degree, but not to a nonpregnant woman who arranges to have an abortion. ${ }^{90}$ He ultimately invokes the conventional wisdom of a policy argument, suggesting that it is "perfectly reasonable for Parliament to discriminate between the nonpregnant woman who nervously administers to herself some abortifacient in the solitude of her own bedroom, and the non-pregnant woman who calls in the "backstreet" or "professional" abortionist." certainly appears to have been quite prepared to extend the criminal sanction to a nonpregnant woman who administers a nonnoxious substance to herself, the legislation itself remained unextended. And it may be that Brian Hogan's proposition, notwithstanding that it was formulated prior to the enactment of the therapeutic exception, remains a reasonable one, particularly in light of the development of postcoital contraceptives.

Despite Glanville Williams' concern with the "ferocious" nature of early abortion legislation, ${ }^{92}$ he himself has noted that it was not the practice to prosecute the consenting woman in abortion cases because it was difficult to "persuad[e] a jury to convict the mother for what many regard as an imaginary crime." "93 Indeed, in the first half of the twentieth century, justices of the peace in England refused to issue process against women upon whom abortions had been performed. ${ }^{94}$ This practice of not prosecuting women has led two preeminent legal scholars to suggest that the issue of the extent of the criminal liability of the woman herself is not "of great practical importance." "However, while they are

85. Smith and Hogan, Criminal Law, 343; see also R. v. Osborn (1920), 84 J.P. 63 (C.C.C.).

86. (1890), 24 Q.B.D. 420 (C.C.A.).

87. (1907-08), 24 T.L.R. 893 (C.C.A.).

88. Glanville Williams, Criminal Law, The General Part (London: Stevens and Sons, 1953), 521

89. $1861,24 \& 25$ Vict., c. 100.

90. Brian Hogan, "Victims as Parties to Crimes," Criminal Law Review (1962): 683, 690; see also Smith and Hogan, Criminal Law.

91. Ibid.

92. Glanville Williams, The Sanctity of Life and the Criminal Law (London: Faber and Faber, 1948), 145.

93. Ibid., $145-46$

94. Ibid., 146; Comment, “Abortion: Is Prosecution's Principal Witness Liable to be Indicted?” Joumal of Criminal Law (1945): 1

95. Smith and Hogan, Criminal Law. undoubtedly correct to identify the significance of a policy of nonenforcement in a particular context, I would submit that the practical importance of the law is not a universal constant. It can and does change in different social, historical, and political contexts. A policy of nonenforcement implies political consideration and decisions. Even the most anachronistic criminal offence (such as blasphemous libel for instance ${ }^{96}$ ) may be dredged up and proceeded with if a group or individual offends the body politic in some way.

With respect to abortion in the current Canadian context, the decision to invoke or not to invoke the criminal sanction is as much a political decision as a legal decision, and the process is in fact a relatively interactionist one. In his longtime advocacy of women's right to choose in matters of abortion and in his public challenge to the law, Dr. Henry Morgentaler has both in the past and in the current context adopted a political posture which has invited and witnessed a political response. ${ }^{97}$ It well be that in a different context, women themselves may face the prospect of prosecution; this does not suggest that women should invite prosecution. But the analysis in this respect must explicitly acknowledge the various levels and terrains on which this intertwined issue of criminal law and social life is placed. If we are to assess the theoretical and practical legal implications of recent developments in the area of contraceptive and abortion technology and pharmacology, then we must have a clear understanding of the extent of women's liability and, most important, cogent arguments for limiting that liability.

\section{Canadian Criminal Law}

In examining the course of the abortion prohibition in Canadian criminal law, it is instructive to have regard to similar legislative enactments in the United States, for while English legal tradition has been more significant for Canadians, legislative developments in the United States also played a large role in helping to shape Canadian abortion law. The United States social historian James Mohr has argued that there was an upsurge of abortion activity in the middle decades of the nineteenth century in the United States, which elicited a dual response: the agitation of the medical profession for stricter legislation, and the enactment of legislation which for the first time expressly extended the criminal sanction to women who sought or induced their own abortions. ${ }^{98}$ He suggests that this was an attempt on the part of legislators to "save women from themselves." 99 The implication that the legislation was motivated by sentiments of protectionism or paternalism is interesting, even tantalizing. It may suggest a parallel between changes in infanticide and changes in abortion, involving the belief that pregnant

96. R. v. Lemmon, R. v. Gay News Ltd., [1979] 1 All E.R. 898 (H.L.)

7. Bernard Dickens, "The Morgentaler Case: Criminal Process and Abortion Law," Osgoode Hall Law Journal 14 (1976): 229. Bernard Dickens documents the almost religious zeal which attended Dr. Henry Morgentaler's first round of prosecutions. See also Eleanor Pelrine, Morgentaler (Scarborough: Signet, 1976) and Henry Morgentaler, Abortion and Contraception (Toronto: General Publishing, 1982), ix-xiii.

98. Mohr, Abortion in America, 124. He refers specifically to the New York legislation of 1845-1846. 99. Ibid., 128 . 
women were slightly unbalanced and in need of protection. ${ }^{100}$ However, I will argue in due course that the image of women that is reflected in the legal and medical literature of the period does not suggest that women who seek abortions experience any sort of diminished responsibility or peculiar pathology; indeed, that image is in direct contrast to the image of women that is reflected elsewhere in medico-legal and criminological literature. ${ }^{101}$

From James Mohr's work, it appears that the states were active in the late nineteenth century in legislating with respect to both abortion and contraception. In 1847, the State of Massachusetts "explicitly joined the issues of contraception and abortion" 102 in a statute that prohibited the distribution of advertisements for contraception. The bill was exhaustive:

Whoever knowingly advertises, prints, publishes, distributes or circulates, or knowingly causes to be advertised, printed, published distributed or circulated, any pamphlet, printed paper, book [etc]...containing words or language giving or containing any notice, hint, or reference to any person, or to the name of any person, real or fictitious, from whom, or to any place...where any poison, drug, mixture, preparation, medicine or noxious thing, or any instrument or means whatever, or any advice, direction, information or knowledge, may be obtained for the purpose of causing or procuring the miscarriage of a woman pregnant with child or [of] preventing, or which is presented as intended to prevent, pregnancy, shall be punished in the state prison for not more than three years or in jail for not more than two and a half years or by a fine of not more than one thousand dollars. ${ }^{103}$

The drive to prohibit the distribution of abortion and contraceptive information received a boost in 1873, when the antiobscenity and antivice movemen succeeded in having the Comstock Act enacted by the United States Congress. ${ }^{104}$ This legislation prohibited the possession or sale of obscene and immoral literature; abortion literature was included in the category of immoral and obscene. Constance Backhouse's research indicates that this legislation was not without significance for legislative developments in Canada. The Canadian Parliament seems to have been as influenced by this type of United States legislation as it was by the British legislation.

Constance Backhouse has noted that the Canadian medical profession became more involved in the public discussion of abortion; she argues that doctors were among the driving forces behind the expansion of abortion

100. Edwards, Female Sexuality and the Law, 78.

101. See, for example, Cesare Lombroso and Enrico Ferrero, The Female Offender (New York: D. Appleton, 1900).

102. Mohr, Abortion in America, 196.

103. Mbid.

103. Ibid. legislation in the late nineteenth century, and that (in matters of abortion) they "were prepared to describe women as 'the chief criminalls]' and recommend consideration even of the death penalty in order to deter them." 105 Doctors were offended by the fact that women who sought abortions were apparently immune from prosecution. While the move to make women who sought abortions criminally liable may be understood as an attempt by physicians to place the burden where they felt it belonged, their equal condemnation of contraception does not lend itself to an explanation based on professional self-interest. The denunciation of abortion and birth control was couched less in terms of the sanctity of life than in an ideology which contemplated and regulated certain forms of sexual behaviour and marital relations. Coupled with this moral perspective was a profound ignorance of human sexuality and the particulars of human reproduction. ${ }^{106}$ The extent to which this ideology was reinforced in Canadian legislation (even if it was not explicitly articulated by Canadian legislators) remains to be seen.

Prior to Confederation, each province had its own Offences Against the Person legislation that regulated abortion. ${ }^{107}$ In 1869 , a consolidated Offences Against the Person $\mathrm{Act}^{108}$ for the new Dominion was enacted; section 59 referred explicitly to "every woman, being with child, who, with the intent to procure her own miscarriage." 109 When the consolidated Criminal Code was enacted in $1892,{ }^{110}$ the law was amended in a material particular with respect to women and abortion: "Every woman is guilty of an indictable offence and liable to seven years' imprisonment who, whether with child or not, unlawfully administers to herself or allows to be administered to her any drug or other means or other noxious thing, or unlawfully uses on herself or permits to be used on her any instrument or other means whatsoever with intent to procure miscarriage."11

It is not easy to explain why the legislation was changed in this way; the following discussion is more exploratory and speculative than conclusive. The House of Commons and Senate debates are interesting but they do not provide the key; they merely rule out any sort of explicit conspiracy theory. Indeed, the silence itself is striking: the amendment to the abortion section respecting a woman who administers to herself a substance in an attempt to induce her own miscarriage, whether or not she was pregnant, was not the subject of a single comment in either house. ${ }^{112}$

At the same time, Canadian criminal law was amended in one other important respect. ${ }^{113}$ Section 179 (c) of the consolidated code provided that

105. Backhouse, "Involuntary Motherhood," 75.

106. Angus McLaren, "Birth Control and Abortion in Canada 1870-1920," Canadian Historical Review 59 (1978): 319, 324-25, discusses physicians' advice to women that the safe period for unprotected sexual intercourse was midcycle.

107. Backhouse, "Involuntary Motherhood," 67-71. She notes that Canadian legislators tended to prescribe harsher penalties (including the death penalty) for abortion than was provided for in the
English legislation.

108. $1869,32-33$ Vict., c. 20

110. $1892,55-56$ Vict., section 29

111. Section 273.

112. See Canada, House of Commons, Debates (1892).

113. Backhouse, "Involuntary Motherhood" 117. 
everyone who "offers to sell, advertises, publishes an advertisement of or has fo sale or disposal any medicine, drug or article intended or represented as a mean of preventing contraception or causing an abortion" "114 was guilty of an indictable offence and liable to imprisonment for two years. Constance Backhouse suggest that this amendment was based on the United States Comstock Act ${ }^{115}$ and she argues that "by defining contraceptives and abortifacients as obscene the Canadian statute went far beyond anything yet seen in English legislation."116 Recorded debates in the House of Commons gives no indication of legislative intention in this respect. ${ }^{117}$ One opposition member, referring to section 179 as a whole, cautioned that "we should take care not to err on the side prudishness," 118 and argued: "A man may have in his possession a picture which some people would object to as being indecent, which is not necessarily indecent, and there are many pictures imported by exhibitors which, in the eyes of the inexperienced might be supposed to be indecent, and it would be well for us to see that we do not go too far in this matter."119 The Minister of Justice seemed to appreciate these remarks, but he noted that the government had received many petitions for the legislation and insisted that "there can be doubt it is needed for the purposes of preventing indecent shows and pictures and photographs."120

There was less than passing reference to the inclusion of contraception and abortion literature in the obscenity section. Clearly we need to look beyond the formal letter of the law and beyond the legislative debates to understand these changes. We are able, however, to consider the implications of the amendments and of the effects they may have had on women's lives. I would argue that the addition of section 179(c) to the Criminal Code gives the change in section 273 a little more meaning. Standing alone, the provision that prohibits a nonpregnant woman from administering to herself a substance to induce the miscarriage of a nonexistent pregnancy does lend itself to being described as an "absurdity," as one Canadian legal scholar suggested in $1893 .^{121}$ The impossibility of procuring a miscarriage when no pregnancy existed might not have attracted the attention of the legislature. It is more likely, though, that Parliament accepted the view of the medical profession that women, whether with child or not, should be as liable to the criminal sanction as doctors themselves were. Moreover, the joining of abortion and contraception in section 179(c) may suggest that the new section 273 laws were intended to apply to women who believed they were pregnant when they were not, as well as women who wanted to ensure that no pregnancy developed. The net effect of the two sections of the new code was to cover al aspects of fertility control - even the efforts of individual women who were unaided and not pregnant.

114. Criminal Code, $1892,55-56$ Vict., c. 29

115. See Mohr, Abortion in America, 196.

116. Backhouse, "Involuntary Motherhood," 119

117. Canada, House of Commons, Debates, (May 25, 1892), 2969-971

118. Debates, 2969.

119. Ibid.

120. Ibid.

121. Taschereau's Criminal Code of the Dominion of Canada as Amended in 1893 (Toronto: Carswell Co., 1893), 276. This commentary urged that section 273 "ought to be read in the English Act, and section 247 , c. 162 , R.S.C. [sic], 'Every woman being with child' ',
This early legislative linking of abortion and contraception challenges some contemporary work which insists on a complete separation. ${ }^{122}$ While modern developments in medicine tend toward some fusion of the two, clearly this is not a recent phenomenon. The medical profession in the nineteenth century viewed contraception and abortion as inseparable and equally unacceptable, ${ }^{123}$ and it appears that the Canadian criminal law did as well. And whereas in the nineteenth century this joining led to a prohibition of both, it may be (paradoxically) that this identified relationship in the current context could facilitate the repeal of the criminal prohibition.

\section{The Course of the Canadian Legislation}

The view that the unaided and nonpregnant women was not the target of the English criminal law seems to have been adopted by many commonwealth jurisdictions whose criminal law in this respect is derived directly from the 1861 Act. ${ }^{124}$ A notable exception seems to be Bermuda, whose Criminal Code renders the individual woman liable whether or not she is pregnant. ${ }^{125}$ Thus in both Bermuda and Canada (until the 1953-54 Code), the nonpregnant woman who attempted her own miscarriage was placed on the same footing as a pregnant woman who sought the assistance of another in the matter of abortion.

This particular departure from the English position challenges the insistence that the abortion prohibition was intended to protect the fetus, ${ }^{126}$ for in the nonpregnant woman there is no fetus to protect. James Mohr interprets this legislative development as an attempt to save women from themselves; ${ }^{127}$ however, it may also be interpreted as a widening of the net in terms of state control of women's sexuality and reproduction. While section 179(c) of the first Canadian Criminal Code ${ }^{128}$ made it an offence to advertise or sell contraceptives or abortifacients, section 273 made it an offence for women, pregnant or not, to use them.

Section 273 was not altered until the 1953-54 Code was introduced. In 1954 , section $237(2)$ set out the liability of a woman seeking to terminate her pregnancy by herself, referring to "every female person who, being pregnant, with intent to procure her own miscarriage, uses any means or permits any mean

122. See, for instance, Dellapenna, "The History of Abortion," 417; Tunkel, "Modern Anti-Pregnancy Techniques."

123. McLaren, "Abortion in Canada;" see also Angus McLaren, Birth Control and Abortion in Nineteenth Century England (London: Croom Helm, 1978), 116-29.

124. See Bernard Dickens and Rebecca Cook, "The Development of Commonwealth Abortion Laws," International and Comparative Law Quarterly 28 (1979): 424

125. Ibid., 425 , note 14

26. See Dellapenna, "The History of Abortion," 403-407; Dickens, Abortion and the Law, 32 Glanville Williams has suggested that the offence of abortion "was invented for the protection of the unborn child." While this may have been the position of the law historically, it can be argued that the twentieth century witnessed a reconsideration. Glanville Williams "I can be argued Abortion," British Joumal of Criminology 4 (1963-1964): 557, 557-58. As he has suggested. "The chief evil of an abortion is no longer thought to be the loss of the unborn child but the injury done to the mother by the unskilled abortionist." Williams "The sanctity of child but the injury done 127. Dellapenna, Abortion in America, 128.

128. $1892,55-56$ Vict., c. 29 
to be used for the purpose of carrying out her intention." 129 The parliamentary debates are once again of little assistance in determining legislative intent. It has been noted elsewhere ${ }^{130}$ that the debate centred on the significance of the deletion of the word "unlawfully" from the new code. ${ }^{131}$ Canadian Commonwealth Federation (C.C.F.) Member of Parliament Stanley Knowles wanted the assurance of the Minister of Justice that a doctor "who performs such an operation for the purpose of saving the life of the mother" would be insulated from prosecution. ${ }^{132}$ The Minister responded:

..I am sure he would because there would be no mens rea in a case of that sort, and in all these cases, without it being specifically mentioned in each section, it is necessary for the crown to prove a guilty mind upon the part of the accused, whether it is so specified or not. I am sure my hon. friend would agree that it is very desirable that when that guilty mind is present, as in the case of a doctor, he should be held to account criminally. ${ }^{133}$

He added: "Most reputable doctors are very hesitant about performing an operation of this kind unless they take very careful precautions against falling into difficulties of this sort."134

The reference to a woman who, "being pregnant," attempted to induce her own miscarriage or allowed a miscarriage to be procured appears not to have figured in the debate. Nevertheless, its significance for our purposes here is considerable: it places the unaided and nonpregnant women on a different footing than a doctor or any other person who performs an abortion. This section of the Criminal Code remained unaltered by the 1969 amendments despite the extensive provisions regarding therapeutic abortions. ${ }^{135}$

\section{Women's Resistance to the Abortion Probibition}

It has become axiomatic to note that abortion has been practised in all societies: "from time immemorial, women have tried to control their own fertility and avoid the conception or birth of unwanted children." 136 And, while abortion may well be described as a traditional female form of birth control, ${ }^{137}$ the methods

129. R.S.C. 1953-54, c. 51. Earlier codes had retained the phrase "whether with child or not" in this section. See R.S.C. 1906 , c. 146; R.S.C. 1927, c. 36, section 304

130. J.J. Lederman and G.E. Parker, "Therapeutic Abortion and the Canadian Criminal Code," Criminal Law Quarterly 6 (1963-1964): 36, 69

131. Canada, House of Commons, Debates (Feb. 26, 1954); 2482-83.

132. Debates, 2483.

133. Ibid.

135. Criminal Law Amendment Act, S.C. 1968-1969, c. 38, section 18.

36. Moya Woodside, "Attitudes of Women Abortionists," Howard Journal 11 (1963): 93, 93; see also Linda Gordon, Woman's Body, Woman's Rigbt: A Social History of Birth Control in America (Middlesex: Penguin Books, 1977).

137. McLaren, "Abortion in Canada," 231 employed by women over the centuries undoubtedly have changed in response to the development of greater knowledge of human reproduction and to the various forms of legal prohibition. The history of the abortion prohibition in Anglo-Canadian jurisprudence may reveal the course of legislative and juridical considerations, but the few reported cases in the law reports and the references to parliamentary debates do not give us any real insight into the social significance and impact of that law. It is to the social historians of birth control and abortion and to feminist historians one must turn in order to understand the rea importance of abortion and of the law in the lives of women. What we find from this research is of profound significance in the current context, given the development of menstrual therapies ${ }^{138}$ which may simplify the procedure for abortion (and indeed may obviate abortions altogether). And while the demand for reproductive freedom and control of our bodies has been a central demand of the present generation of feminists, what emerges from social historical research is that women have always demonstrated an interest in menstrual regulation and the early abortion.

In the nineteenth century, changes occurred in English and Canadian ${ }^{139}$ criminal law relating to abortion, resulting in the erosion of the concept of quickening as a significant moment in pregnancy. Quickening, which refers to the - first movement of the fetus in utero and occurring at approximately the sixteenth week of pregnancy, was thought to represent the first moment of life of the unborn infant. While the early Christian church had stressed the sanctity of life from its very beginning, ${ }^{140}$ this view was modified and a distinction was drawn between an embryo formatus and an embryo informatus. ${ }^{141}$ It was thought that only at quickening.was a fetus infused with a soul. The position of the common law with respect to abortions procured before quickening may be stated briefly: they were not criminal offences. ${ }^{142}$ Abortion after quickening was a great misprision (misdemeanour). The first prohibition of abortion before quickening was contained within Lord Ellenborough's Act, ${ }^{143}$ although quickening was retained to distinguish between the greater and lesser offences. In England in 1837, reference to quickening in the abortion prohibition was removed altogether. ${ }^{144}$

While the medical and legal men of the day may have decided that quickening was no longer to be of any consequence, the historical literature (much of which comes from the journals and papers of medical men) indicates that for women who sought to prevent or terminate an unwanted pregnancy, the concept of animation as marked by quickening remained firmly part of their

138. "Menstrual therapy is a generic term describing medical and surgical procedures performed on the uterus for diagnostic and therapeutic indications. This includes menstrual aspiration, and the use of drugs, such as prostaglandin, as well as more traditional dilation and curettage." Bhiwandiwala et al., "Menstrual Therapies," 275; see also Cook and Dickens, "Emerging Issues," 44

139. See Backhouse, "Involuntary Motherhood," 69-71.

140. D. Seaborne Davies, "The Law of Abortion and Necessity," Modern Law Review 2 (1938-1939): $126,131$.

141. Ibid.; see also Williams, The Sanctity of Life, 141-44; Dickens, Abortion and the Law, 14-16. 142. Dickens, Abortion and the Law, 14-16; Williams, The Sanctity of Life, 141-44.

143. $1803,43 \mathrm{Geo} . \mathrm{m}, \mathrm{c} .58$.

144. Offences Against the Person Act, 1837, 7 Wm. IV \& 1 Vict., c. 85, section 6. 
Men's attitudes toward procreation might have changed but women still retained the traditional view that life was not present until the foetus quickened. Until that time they considered it their right to conduct themselves in any way they saw fit. Moreover, until animation, they perceived themselves not as pregnant, but as 'irregular'; they took drugs not to abort, but to restore the menses. ${ }^{145}$

This commitment to quickening did not evaporate. In 1861, a United States physician recounted the following discussion with one of his women patients:

[Patient] "Well, I can trust you, I suppose, and it is this. I am about three months gone in pregnancy, and I have made up my mind that I will not slave myself with another child." As she spoke her eyes flashed and her voice and manner evinced her positive determination to do as she said. Looking at her steadily in the face, I said, "Madam, are you aware that willfully to cause an abortion is a criminal offence - murder to all intents and purposes?"

[Patient] Nonsense, doctor, there is no life yet, and a great many persons do so and think it not harm, nor do I; you need not be afraid....

[Patient] Doctor, I do not believe it is a crime.... ${ }^{146}$

Patricia Knight's research of a yet later period in English history reveals the same tension between women and the professions of law and medicine. She describes doctors as being "constantly surprised" and "annoyed" when women refused to believe that abortion was wrong. She reports that a judge in 1899 complained, "it is often quite impossible to make women see the moral difference between early getting rid of the product of conception and using methods to prevent pregnancy

What emerges clearly from these accounts is not only the insistence of women on their right to control their fertility in this way, but also the frustration of men who experienced the futility of trying to prevent women form controllng their fertility. Patricia Knight refers to the lament of another doctor who gave evidence before the National Birth-rate Commission in England: "[women] cannot understand why a doctor's conscience varies from theirs. They say, it can't be

145. McLaren, "Abortion in Canada," 35

146. Dr. J. H. Toner, quoted in Malcolm Potts, Peter Diggory, and John Peel, Abortion (Cambridge: Cambridge University Press, 1977), 166. For similar accounts by doctors, see McLaren, "Abortion in Canada," 333-34; McLaren, Nineteenth Century England, 124; Knight, "Women and Abortion in Victorian and Edwardian England," History Workshop 4 (1977): 57, 64-65.
147. Knight, "Women and Abortion," 64. alive yet, it is only so many weeks.... It is a great comfort to me that it is criminal as well" 148 All of these accounts illustrate the extent to which women have regarded the very early stages of pregnancy as "their own" and have refused to accept the distinction between the "night before" and the "morning after" with respect to birth control. If we can appreciate women's perspective on their own fertility, we are in a better position to see clearly why the rapidly changing medical technology in the areas of contraception, menstrual regulation, and abortion is of such importance.

Well into the twentieth century, the belief persisted among great numbers of English women that self-induced abortion before the third month of pregnancy was legal. ${ }^{149}$ In her 1964 study of English women who were convicted of performing abortions, Moya Woodside noted that "in the early weeks of pregnancy, they did not see anything wrong in using the douche as a delayed contraceptive or regulatory measure." 150 There can be little doubt that attempts to self-induce a miscarriage were the first line of attack by women fearing they had become pregnant. ${ }^{151}$ And, while it is impossible to know women fearing they of early self-induced and illegal abortion in the nineteenth and twentieth centuries, ${ }^{152}$ recent historical work suggests that ordinary married women relied on abortion as a major method of fertility control. 153 That "respectable" women would attempt or seek abortion clearly confounded the medical and legal observers. This was not to be confined to the Victorian and Edwardian years: recent work which considers the impact of the liberalization of English abortion law has also noted that the experts have been perplexed by this attitude. ${ }^{154}$

While exact figures are elusive, it seems that women in great numbers considered abortion to be an acceptable and necessary method of postconception fertility control. Dr. Marie Stopes, a leading English birth control advocate of the early years of the twentieth century, told the annual meeting of the Medico-Legal Society in 1931: "I think I may startle you by saying that in three months over 20,000 women have asked me for abortions and told me why they wanted them. They asked me of course in vain; but one can be pretty sure they did not ask in

148. Ibid.

149. Angus McLaren, "Women's Work and The Regulation of Family Size: The Question of Abortion in the Nineteenth Century," History Workshop 4 (1977): 70, 75.

150. Woodside, "Attitudes of Women Abortionists," 108. She noted that "douching" used by women for personal hygiene and as a method of postcoital contraception was also "widely practiced as a method of inducing miscarriage when pregnancy is feared to have started." She quoted women in prison as saying that "sixty per cent of married women use the Higginson's syringe regular [sic] every month, just to be sure they bring the period on...." and "Most women do syringe themselve if they go a week or fortnight over, to see if they can bring it on themselves." Ibid., 98-99.

151. McLaren, "Abortion in Canada 1870-1920," 33; see also Madeleine Simms, "Abortion: The Myth of the Golden Age," in Controlling Women: the Normal and the Deviant, ed. Bridget Hutter and Gillian Williams (London: Croom Helm, 1981): 168, 169-71; Linda Gordon, Woman's Body, Woman's Right, 39.

152. Potts et al., Abortion, 159, describe this dilemmma in almost poetic fashion: "[B]uried, like the fragments of an almost totally destroyed building in an archeological site, are the outlines of a problem which was to become increasingly important as the [nineteenth] century proceeded." 53. See McLaren, "Women's Work"; McLaren, "Abortion in Canada," 323, 327-36; Knight "Wome and Abortion," 64.

154. See Greenwood and Young, Abortion in Demand. 
vain from the commercial firms who flourish a few yards away...." ${ }^{155}$ And while Marie Stopes consistently and adamantly refused to perform abortions, ${ }^{156}$ it appears that she was prepared to advise women on how they might keep their menstrual periods regular: "To do this she suggested taking a dose of quinine 2 or 3 days before the period was expected and a hot bath the night before it was due." 157

Dr. Stopes may have been one of a small number of physicians who were prepared to assist women in menstrual regulation, as distinct from abortion. The legal advice offered to medical practitioners by Stanley Atkinson ${ }^{158}$ encouraged them rather to engage in deceit and misrepresentation in this respect: "Should a placebo be indicated to appease a woman who wishes to 'bring on the courses', or to 'remove the obstruction', and who as yet presents insufficient signs of pregnancy, the medical adviser must refrain from prescribing 'reputed abortifacients', and will be wise in indicting the recipe in English. Sudden amenorrhea in nubile women presumes pregnancy." 159 Mr. Justice Darling had held in $R$. v. Brown ${ }^{160}$ that it was within the law for a medical practitioner to supply a substance to a woman seeking an abortion if the substance was to his knowledge not capable of causing the abortion. However, with respect to unscrupulous individuals who made a business of selling supposed abortifacients to women, he suggested that the law would provide a remedy: "in a case where an absolutely innocuous substance is supplied an indictment would lie for false pretences, though not for inciting for the attempt to procure abortion."161

155. She spoke as a discussant, responding to a paper given by George Allardice Riddell, "Ancient Laws and Modern Women," in Transactions of the Medico-Legal Society 1929-30, ed. Gerald M. Slot and Modern Women," in Transactions of the and Ever whereof shespoke. hn addition to he wo. Heffer and letters from women and men seeking advice for birth control and sexne leter, writen by a manis Marie Stopes" work and a suggestion for her critics: '[Dear Dr. Stopes] In sincerity I wite to wish you the best of your luck in your Action or which I have just fnished reading in the Daily Mail. To the men who do condemn you, I would like to give one month as a mother in a working man's home, Four bedrooms and sedllery with whitewashed walls, stairs devoid of capet in an obscure corner. The kitchen which serves as dining room, bakehouse and bedroom when the mother is ill, can boast of papered walls and gas light. The men who condemn you would have to run this house the weekly wage would be \pm 3 (that is more than average) have two babies $11 / 2$ years an three years and prepare for the third.... They would have to feed that family, wash for it, bake fo it, clean for it, make a good big dinner for $11 / 2 \mathrm{~d}$ each, make old clothes into new. This would be fairly hard but 'God Help Them!' what would they do if they were handicapped with pregnancy. You wouldn't have one enemy, they would all commit suicide... Yours truly, an admirer." Ruth Hall, ed., Dear Dr. Stopes: Sex in the 1920s (Middlesex: Penguin Books, 1981), 17-18.

156. Simms, "Abortion: The Myth of the Golden Age," 169-170

157. Barbara Brookes, "The llegal Operation: Abortion, 1919-39," in The Sexual Dymamics of History. Men's Power, Women's Resistance, ed. London Feminist History Group (London: Pluto Press, 1983), $165,167$.

158. Stanley Atkinson, The Law in General Medical Practice: Some Chapters in Every-day Forensic Medicine (London: Henry Frowde, Oxford University Press, 1908).

159. Bbid., 148.

160. (1899), 63 J.P. 790 (C.C.C.)

161. R. v. Brown, 791. Mr. Justice Darling held strong views on the subject of women and abortion. Elsewhere he is reported to have referred to the problem of "race suicide" and the threat that the practice of abortion posed to the British Empire See Brookes, "Illegal Operations," 170. Mr Justice Darling was not an isolated voice in this respect; Anna Davin, "Imperialism and Motherhood,"
This combination of legal advice and medical practice may shed some light as to why illegal abortions which were detected or admitted tended to be performed later in the pregnancy. Alfred Swaine Taylor's text on medical jurisprudence suggested: "Criminal abortion is rarely attempted before the third month. It is perhaps most common between the fourth and fifth month because then a woman begins for the first time to acquire certainty of her pregnancy." "162 Alfred Taylor was clearly, albeit implicitly, attesting to the significance of quickening in women's experience of pregnancy. Thus the phenomenon of "late" criminal abortions may be explained by initial use by women of purgatives or abortifacients on themselves before quickening, followed by recourse to an abortionist if all else failed. ${ }^{163}$ The role of the licensed medical practitioners in this is not an untainted one if they, acting on Stanley Atkinson's above-noted advice, not only dissuaded women from seeking abortion, but deliberately misled women patients in the matter of diagnosis and treatment.

\section{Medical Attitudes Toward the Therapeutic Exception}

Although the therapeutic abortion exception to the criminal prohibition on abortion did not become legislatively entrenched until the late 1960s in Canada and England, still the concept and criteria to be used had been much discussed in the medico-legal literature for well over a century. Thus I would argue that the criminal prohibition of abortion to be simply reflect medical opposition to abortion because the argument for the therapeutic exception appeared in the medical discourse as early as the 1750 s. ${ }^{164}$ This is not to suggest that doctors did not actively support the general criminal prohibition. Angus McLaren has suggested that nineteenth century Canadian doctors were afraid that they were vulnerable to being seduced or victimized by women who sought to "bring on the courses" or an outright abortion itself. ${ }^{165}$ This view tends to be supported by Stanley Atkinson's admonitions to his medical readers. ${ }^{166}$

Some of the historical work in this area illustrates that some, perhaps many,

History Workshop 4 (1978): 9, describes the formation of an ideology of motherhood in the early years of the twentieth century in England, English women having the "duty and destiny" to be mothers of the race. In the Canadian context, MacLaren, "Abortion in Canada," has noted a simila concern of English Canadians with respect to the spectre of high fertility rates of Irish and Quebec Catholics.

162. Thomas Stevenson, ed., The Principles and Practice of Medical Jurisprudence (London: J. and A Churchill, 1883), 178-79. Potts et al,, Abortion, 158-59, refer to a study conducted in 1845 of 2000 women patients the Manchester Lying-In Hospital. Of the 2000 women, 747 admitted to having had one or more abortions, only half of which had been in the first trimester of pregnancy.

163. See, for example, Frederick McCann, "Criminal Abortion and Measures Necessary to Restrict the Sale of Abortefacient [sic] Drugs," Transactions of the Medico-Legal Society 23 (1928-29): 37, 43.

164. Angus McLaren, Reproductive Rituals (London: Oxford, 1984), 127.

165. McLaren, "Abortion in Canada," 331-32.

166. "Neither for love nor for money must the practitioner be beguiled into performing an illegitimate operation. He must decline to relieve, under anaesthetic, a wedding-ringless young woman of the shame, as yet perhaps unknown to herself. He must not assist a wife in illegally limiting the numbers of her children. Indeed, if such seductive proposals are made, the proposers should be warned of the felonious character of their desires; they should be summarily dismissed srefernbly after the actual words of the penalizing Act have been recited to them slowly and deliberately:" Atkinson, General Medical Practice, 147. 
physicians followed this advice in an attempt not only to dissuade women from proceeding with the attempt, but also to deliver a homily on the inherent evil of such conduct. ${ }^{167}$ Doctors assumed a role in this which was difficult to pursue with success - the role of moral intermediary. Indeed, the literature is replete with illustrations of the failure of doctors to "comprehend the feelings of womete with with unwanted pregnancies, and of the determination guilt felt by the abortion against all odds,"168 their anger at the absence of guilt felt by the women who approached them, ${ }^{169}$ and frustration at their inability to deter women from their chosen course of action. ${ }^{170}$ In sum, as Angus McLaren has observed in a rather understated manner, "doctors were never to be totally successful in convincing women of the immorality of abortion."171 Thus while the criminal law in the nineteenth century may have become increasingly influenced by medical discourse, and the role of medical men a me increasingly may have become enhanced, ${ }^{172}$ it is clear that this development at the level of medico-legal discourse and practice, while it may have become definitive, was not determinative with respect to women's lives. Regardless of the law and of medical moral suasion, women continued to insist on method of fertility control.

Susan Edwards interrogates "female sexuality as it is socially constructed and as it is reproduced in sex laws"173 and has identified what she calls the "female paradox": an "image" of female sexual passivity in she calls the "female "understanding" of female sexual aggression in the courts. ${ }^{174}$ In fact what she has noted is a contradiction between theory and practice which is not confined to any one discipline or discourse. With respect to women and reproduction she practice: "Whilst reproduction and related functions were features of the natural life process, they were, at the same moment regarded as 'pathological' and thereby frequently considered a cause of mental instability ",175 'pathological', and menstruation, pregnancy, childbirth, and menopause were all identified as conditions which contributed to women's propensity to be hysterical and unstable, and how this perception of women's gynecology influenced both the unstable, and how this perception of
theory and practice of criminal law. ${ }^{176}$

Interestingly enough, Susan Edwards is silent with respect to abortion, although admittedly her primary focus is on the criminal law relating to sexual offences. Nevertheless, it would appear that the medical jurisprudence on abortion is somewhat at odds with the literature on which Susan Edwards relies.

It is not at all apparent from the nineteenth century literature that women who

167. See Potts et al., Abortion; Mclaren, "Abortion in Canada"; McLaren, Nineteenth Century England; Knight, "Women and Abortion."

168. Knight, "Women and Abortion," 65

169. McLaren, "Abortion in Canada," 334

170. Potts et al., Abortion, 166-67.

171. Mctaren, "Abortion in Canada," 335

172. Edwards, Female Sexuality and the Law, 21

173. Ibid.

174. Ibid.

175. Ibid., 75 .

176. 1bid., 91-92. sought abortions were perceived to be acting impulsively or irrationally. The desire to avoid the consequences of "illicit commerce" either by way of concealment of birth or by abortion was comprehensible even to the earliest writers on the subject: "The practice of causing abortion is resorted to by unmarried females, who, through imprudence or misfortune have become unmarried females, who, through imprudence or misfortune have become pregnant, to avoid the disgrace which would attach to them from having a living child; and sometimes it is even employed by married women, to obviate repetition of particularly severe labour pains, which they may have previously
suffered."177 While the desire to escape "the consequences of sin $^{\prime \prime 178}$ suffered. While the desire to escape "the consequences of $\sin ^{\text {"178 }}$ was denounced, it was done in terms that did convey an understanding of the rational though immoral reasons therefor. Indeed, the advice offered by Stanley Atkinson to doctors to read the prohibiting legislation "slowly and deliberately" women attested to the need to coerce or shame women into changing their minds and their ways - surely not a course that could be followed if the listeners were considered to be irrational or mentally disturbed. The suggestion that women had been "imprudent" implied that they were capable of prudent behaviour. The irony of course is that it seems that women were thought to be imprudent by themselves, for one never encounters in this literature any reference to their equally imprudent lovers.

As indicated at the outset of this section, the medical profession seemed to be content with the prohibition as reason enough not to become involved with abortion. However, to say only this is to ignore the way in which the therapeutic exception to the criminal prohibition became part and parcel of "regular" medical practice. Malcolm Potts and his colleagues maintain that "abortion for strictly therapeutic reasons was accepted by early that "abortion for obstetricians." 180 It is important to remember that until 1967 in England ${ }^{181}$ and until 1969 in Canada ${ }^{182}$ there were no express provisions allowing for therapeutic abortions. There had been some consideration of the issue in England in 1846 when the Criminal Law Commissioners had recommended that "acts done in good faith with the intention of saving the life of the mother whose miscarriage is intended to be procured" be exempted from the criminal prohibition." ${ }^{183}$ Such a provision was not to be included in the law until well over a century was to pass.

The fact that the legislation prohibited abortions "unlawfully" procured was

177. Theodric Beck and John Beck, Elements of Medical Jurisprudence (London: Longman, Orme, Green, and Longmans, 1838), 230.

178. Dr. Robert A. Lyster, discussant at the paper given by McCann, "Criminal Abortion," 54 , suggested that the rationale for "drastic" antiabortion legislation in the nineteenth century was probably the "moral" factor: "[B]ecause abortion was then regarded essentially as a method of escaping 'the consequences of sin', and this was merely part of the general plan of making moral wrongness
suffer as much as possible." suffer as much as possible."

179. Atkinson, The Law in General Medical Practice, 147

80. Potts et al., Abortion, 155. They quote a French obstetrical text published in 1840 , which they say was translated and issued in many editions in North America and Britain: "Like premature delivery, [induced abortion] is now received as an obstetrical operation, and it only remains for us to indications, and the most expeditious and least dangerous means of accomplishing the object."

181. Abortion Act, 1967, c. 87 (U.K.)

182. Criminal Law Amendment Act, S.C. 1968-69, c. 38, section 18.
183. Dickens and Cook, "Commonwealth Abortion Laws," $429-430$. 
taken by the medical profession to imply a recognition of lawful abortions. ${ }^{184}$ The earlier medical literature is replete with detailed discussion of the fine distinction between the induction of abortion and the induction of premature labour, ${ }^{185}$ the latter practice being resorted to when the unborn child was thought to be viable and when the mother's life was in danger. ${ }^{186}$ In his early text on medical jurisprudence, however, Joseph Chitty took the position that the induction of premature labour was improper and illegal:

We may all concur in the wish to save the life of a mother under such a charge; but in a strict judicial view, if there be a mere possibility of the child born alive within seven months, being by extreme care or under any circumstances kept alive for any considerable time, it should seem that the culprit, who deprives the infant of all chance, ought to held criminally responsible. ${ }^{187}$

We may infer from this passage that Joseph Chitty was not prepared to read the abortion prohibition in a sufficiently liberal way as to allow an attempt to save the life of a woman if there was any chance that her unborn child might be able to survive without her.

Medical commentators were aware that they were carving out a distinction in medicine that was not expressly recognized at law. ${ }^{188}$ And yet, at least one of these texts, authored by William A. Guy (professor of forensic medicine at King's College in London), in considering when it might be "legally and morally proper to induce premature delivery," advised that the physician could use any measures which promise to preserve the life of the mother and child when both are threatened." "He further advised that when only one of the two lives might be preserved, "the female herself may use her rights of self-preservation, and choose whether her own life or that of her child shall fall a sacrifice to the means recommended to be used." 190 And while it may well be that the medical jurisprudence texts were not always paragons of legal analysis, ${ }^{191}$ there can be no doubt that they more directly affected and shaped medical practice in this respect

184. See, for example, L.A. Parry, Criminal Abortion (London: John Bale, Sons and Danielsson, 1932) and L.A. Parry, "Abortion: Some Medical, Legal and Sociological Points," Transactions of the Medico-Legal Society 26 (1931-32): 111, 111-13. See also Atkinson, General Medical Practice, $146-150$.

185. Taylor, Medical Jurisprudence, 156, defined abortion as the expulsion of the uterus before the sixth month of gestation, and premature labour (delivery) as the expulsion of the uterus between six and nine months.

186. There was no agreement among the authors of nineteenth century medical jurisprudence texts as to the precise point in time at which the fetus attained sufficient viability to justify the induction of premature labour. For a description of this debate see Joseph Chitty, A Practical Treatise on Medical Jurisprudence: Part I (London: Roworth and Sons, 1834), 406-407.

187. Ibid., 406.

188. See Taylor, Medical Jurisprudence, 178.

189. William Guy, Principles of Forensic Medicine (New York: Harper and Bros., 1845), 145. 190. Ibid

191. Dickens, Abortion and the Law, 98. See also Williams, "The Law of Abortion," 136-37. than did the legislation or case law, which in turn means that they were also more critical for the women who approached medical practitioners for abortions.

This is not to suggest that doctors were indifferent to the law. Indeed, one senses from this literature a greater concern for their professional reputation, well-being, and possible legal liability than for the lives of their women patients. Very early on, the medical man was encouraged to "have regard to his own character" and not to induce premature delivery "unless some other respectable practitioner has seen the patient and has acknowledged that the operation is advisable."192 Constance Backhouse has uncovered similar advice in the nineteenth century Canadian medical literature. ${ }^{193}$ Stanley Atkinson gave his medical readers very detailed instructions: they were to act openly, publicly, and court reasonable publicity; they were to obtain a written concurring opinion from a brother practitioner and written consent from the woman's husband or parents; and a nurse was to be in attendance for the operation. ${ }^{194}$

\section{Legal Recognition of the Therapeutic Exception}

The famous English case of $R$. v. Bourne $e^{195}$ is often heralded as the judicial decision that introduced the lawful therapeutic exception into Anglo-Canadian criminal law. However, as has been noted elsewhere ${ }^{196}$ several years earlier the Saskatchewan Queen's Bench in Re McCready ${ }^{197}$ had had to consider the status of the therapeutic abortion in Canadian criminal law for the purpose of determining whether the accused ought to be extradited to the United States to face a charge of aiding and abetting the procuring of an unlawful abortion. In refusing to accede to the extradition request, Mr. Justice Lamont said that the evidence makes it clear that the operation "might not have been necessary to preserve her life, in which case it was not unlawful." He went on to say that not every abortion is unlawful. ${ }^{198}$

Aleck Bourne's case seems to be the first one in which the therapeutic exception defence was put to the jury. ${ }^{199}$ His patient, a fourteen year old victim a gang rape who had become pregnant, had been referred to him by a doctor who was a member of the Abortion Law Reform Association. ${ }^{200}$ He had not agreed immediately to perform the operation:

I admitted her on June 6th, 1938. I kept her in bed for 8 days to be sure of the type of girl I was dealing with....[He took a swab for

192. Dr. Merriman, quoted by J.A. Paris and J.S.M. Fonblanque, Medical Jurisprudence 1 (London: W. Phillips, 1823), 273

193. Backhouse, "Involuntary Motherhood," 62

194. Atkinson, General Medical Practice, 147

195. [1938] 3 All E.R. 615 (K.B.).

6. Lederman and Parker, "Therapeutic Abortion," 68; Dickens, Medico-Legal Aspects, 39; Dickens and Cook, "Commonwealth Abortion Laws," 430.

197. [1901] 2 Sask. L.R. 46 (Sask. Q.B.).

198. [1901] 2 Sask. L.R., 46.

199. [1938] 3 All E.R., 616, per Macnaghten J.

200. Hindell and Simms, Abortion Law Reformed, 69. Apparently this doctor had first referred the 
pathological examination.] ... The occasion caused a complete breakdown for her morale. All her assumed cheerfulness disappeared as she wept beyond control. This decided me at once that she had to be relieved of her pregnancy. In her was none of the cold indifference of the prostitute. . $^{21}$

He appears to have followed Stanley Atkinson's advice to practitioners to the letter: he acted publicly and in fact invited the prosecution which ensued. Very importantly, he performed the operation as an act of charity and took no fee. ${ }^{202}$ And, most important, he performed the operation after determining that the continuation of the pregnancy would endanger her mental health. This was sufficient, as the trial judge charged the jury: "The law is not that the doctor has got to wait until the unfortunate woman is in peril of immediate death and then at the last moment snatch her from the jaws of death. He is not only entitled, but it is his duty, to perform the operation with a view to saving her life." 203 While the trial judge did not make express reference to the defence of necessity, the case has been taken to have rendered this defence applicable to statutory as well as common law offences. ${ }^{204}$ The acceptance of the defence of necessity based on therapeutic criteria, including the mental health of the woman, was not a small. thing. It opened a small crack in medical practice, and it seems as well to have affected police practice in England in the years following. ${ }^{205}$

It is important to understand the limits of this exception in order to assess the continuing tension between women, doctors, and the criminal law with respect to abortion. I would suggest that we may be able to do this by examining Aleck Bourne's case more closely, including his personal history from that point. While the danger to a woman's mental health formed the backbone of his defence, it is essential to understand his self-imposed limitation: the patient was "an ordinary decent girl, brought up in an ordinary decent way...."206 Had she been "feebleminded" or "of a prostitute mind," her mental health, in Aleck Bourne's judgment, would not have been adversely affected and she would not have been entitled to the abortion. ${ }^{207}$ As has been noted elsewhere, medical determinations

young woman to a Roman Catholic doctor who refused to terminate the pregnancy because the young wom to a Roman Cacholic doctor who refused to terminate the pregnancy because the on."

201. Aleck Bourne, quoted in Hindell and Simms, Abortion Law Reformed, 70. As Keith Hindell and Madeleine Simms observe, "for her innocence and good morals, [Aleck] Bourne rewarded her with an abortion."

202. R. v. Bourne, [1938] 3 All E.R., 616. The issue of fees has consistently been significant in determining whether the doctor acted in good faith, evidence of a large fee giving rise to the inference that the operation was not bona fide for the purpose of preserving the woman's life or
ing inference that the operation was not bona fide for the purpose of preserving the woman's life or
health. See Smith and Hogan, Criminal Law, 341. However, Glanville Williams, relying on the health. See Smith and Hogan, Criminal Law, 341. However, Glanville Williams, relying on the
unreported case of R. v. Bergmann and Ferguson (1948), has argued that "self-interest is not unreported case of R. v. Bergmann and Ferguson (1948), has

203. R. v. Bourne, [1938] 3 All E.R., 618

204. Williams, The Sanctity of Life, 152

205. Williams, "Legal and Mlegal Abortion," 563-64.

206. R. v. Bourne, [1938] 3 All E.R., 619 .

207. Ibid. are made with a sense of "conventional morality" in mind. ${ }^{208}$ Clearly, in Aleck Bourne's decision to proceed with the abortion in this case, there was more than medical judgment contemplated in his categories of women for whom he would and would not be prepared to perform an abortion based on the threat to their mental health. Thus the spurious distinction between "virgins." and "whores" distinction which Susan Edwards insists is intrinsic to the model of female sexuality within sexuality within criminal law's theory and practice, particularly as it exists within the law relating to sexual offences ${ }^{209}$ ) came to be understood to be a medical distinction in the practice of abortion.

Several years later, at a conference convened in England to consider the implications of the then recently enacted Abortion Act, ${ }^{210}$ Aleck Bourne was to confirm that he had regarded the case as "exceptional and had always opposed 'indiscriminate' abortion." 211 He went on to explain his position with respect to the most suitable candidates for abortion: "Now, I think most of you probably agree that most abortions, if they are necessary at all, need sterilisation too; not all of them of course, but a large number do. The grand multipara, who is sagging everywhere - breasts, abdomen, her spirits, her emotions, everything is sagging miserable, depressed: she is the one I have aborted more than any other."212 This later account of Aleck Bourne's thoughts with respect to abortion may not be relevant to the significance of the case; nevertheless it does further illustrate the role he perceived for himself and for other medical practitioners and perhap sheds some light as to why the lor other medical practitioners, and perhaps sheds some light as to why the case came about. He undoubtedly facilitated the opening up of the criminal law in this respect, but it is equally clear that he resisted any liberalization which might allow for recognition of a woman's right to choose ("indiscriminate abortion") or otherwise limit the ability of the righ profession to determine abortion") or otherwise limit the ability of the medica profession to determine the proper grounds for approving the procedure, and any suitable aftercare, such as sterilization. ${ }^{213}$ While the Bourne decision might be described as a benchmark, it would be an exaggeration to suggest that it brought about a dramatic change in medical practice. The concept of the "therapeutic exception" had been taken as established within medical practice.

208. S. Young, "The Politics of Abortion and the Crisis in the National Health Service," Radical Science

209. Edwards, Female Sexuality and the Law and Young, Abortion in Demand, 49.

Justice System (New York: Praeger, 1980); and the New Female Criminal," in The Female Offender: Selected Papers from anith: Misogyny Symposium, ed. Curt Taylor Griffiths and Margit Nance (Vancouver: Crers from an International Simon Fraser University, 1980), 1.

210. Medical Protection Society, The Abortion Act 1967: Proceedings of a Sympostum Held Medical Protection Society in Collaboration with the Rocedings of a Symposium Held by the (London: Pitman Medical Publishing Co. 1969). 211. Bourne, The Abortion Act 1967, 80 .

212. Ibid., 83 .

213. Toward the end of his career, Aleck Bourne abandoned the Abortion Law Reform Association, of (S.P.U.C.) ad long been a member, to join the Society for the Protection of Unborn Children Law Reformed 72 For 85-93.

146-150. For ininal Abortion; Parry, "Abortion Points"; Atkinson, General Medical Practice, Medico-Legal Society in 1931: "As a matter of actual practice therapeutic abortion is recognised 
After the Boume decision, doctors did initially express concern that it would be reversed in another case, rendering them liable again to prosecution. ${ }^{215}$ The result was perhaps predictable enough: the interpretation of the law by medical practitioners varied. ${ }^{216}$ The paradox ultimately resulting from the recognition of the therapeutic exception was that it led to greater uncertainty and inequality of access to abortion, so that in practice there was one law for the rich and another for the poor. ${ }^{217}$ Women who could afford "reputable" doctors who were prepared to make the appropriate referrals were able to have the abortions they sought; those who did not have the requisite financial means to do so sought the assistance of what are often described as "backstreet" abortionists. By the early 1960 s, Victoria Greenwood and Jock Young noted that the law in England had little support. "Large numbers of semi-legal and illegal abortions were taking place. The existence of the private sector demonstrated that existing abortion legislation [sic] applied largely to those without means: 'abortion is like equal pay, the women who are best off get it'."218

The argument for legislative reform in the area of abortion stressed the need for clarification in order that medical practitioners would have more certainty in the legality of their position when performing abortions. ${ }^{219}$ At rock bottom, what underlies such a position is an unquestioned commitment to the right and necessity of the medical profession to as much autonomy as possible in their practice. This ultimately resulted in legislative reform of the abortion law which recognized the autonomy of medical practitioners in this respect, ${ }^{220}$ and which has produced as much uncertainty and inequality in the Canadian context as was previously the case before the legislative entrenchment of the therapeutic exception.

Legislative Entrenchment of the Therapeutic Exception

The inequalities and uncertainties that characterize Canadian abortion law reform derive in large measure from the great discretion vested in the medical profession by the provisions of the therapeutic exception to the abortion prohibition. ${ }^{221}$ The legislation purports to be exhaustive with respect to the

as no crime. No doctor has ever been prosecuted in this country for performing the operation when it has been carried out as a medical necessity. But to be safe, a doctor must adopt certain precautions. Before he carries out the operation, he should get the agreement of a colleague of repute as to the necessity of the operation, and he should obtain the consent in writing of the husband of the patient." Parry, "Abortion Points," 112-13.

215. Williams, "The Law of Abortion," 137.

216. Williams, "Legal and Mlegal Abortion," 564.

217. Williams, The Sanctity of Life, 174; Alice Jenkins, Law for the Rich (London: Gollancz, 1960) Greenwood and Young, Abortion in Demand, 21; Simms, "Abortion," 180-81.

218. Greenwood and Young, Abortion in Demand, 21.

219. See, for example, Williams, "Legal and Mlegal Abortion"; Lederman and Parker, "Therapeutic Abortion."

220. For an analysis of the current Canadian position, see Larry Collins, "The Politics of Abortion Trends in Canadian Fertility Policy," Atlantis 7 (1982): 2.

221. R.S.C. 1970 , c. C-34, section 251 now provides as follows: "(1) Every one who, with intent to procure the miscarriage of a female person, whether or not she is pregnant, uses any means for the purpose of carrying out his intention is guilty of an indictable offence and is liable to imprisonment manner in which legal abortions in Canada are to be performed or obtained However, the fact that the Criminal Code does not require hospitals to establish therapeutic abortion committees, limits the establishment of the committees to hospitals which are either accredited or approved within the meaning of the section, and fails to offer a definition of "health," has lead great inequalities of access and treatment within Canada with respect to abortion. ${ }^{222}$ Significant numbers of eligible hospitals have elected not to committees, ${ }^{223}$ and most of these and professional ethics. ${ }^{224}$ of the Report indicated the have committees, the Badgeley Report indicated that the interpretation of the law as to whether a woman's case qualified for abortion varied from committee to committee across the country.225 This led the committee to conclude that "the criteria (requirements and guidelines) used by hospital therapeutic abortion committees across Canada were inequitable in their application and their consequences for patients." ${ }^{226}$ The significance of religious consequences for induced abortion to the refusal of eligible hospitals to establish the the was, predictably enough, also a factor in the attitudes of individual doctors ${ }^{227}$ And, even with physicians who were in the attitudes of individual doctors. ${ }^{227}$ And, even with physicians who were prepared to perform the procedure, their "personal dislike" of induced abortion was "not always professionally shielded in

"Women, for their part, reported to the Badgley Committee that they often felt "financially gouged" by doctors who extra-billed for the procedure ${ }^{229}$ and

for life. (2) Every female person who, being pregnant, with intent to procure her own miscarriage uses any means or permits any means to be used for the purpose of carrying out her intention is guilty of an indictable offence and is liable to imprisonment for two years. (4) Subsections (1) and (2) do not apply to (a) a qualified medical practitioner, other than a member of a therapeutic abortion committee for any hospital who in good faith uses in an accredited hospital any means for the purpose of carrying out his intention to procure the miscarriage of a female person, or (b) a female person who, being pregnant, permits a qualified medical practitioner to use in an accredited or approved hospital any means described in paragraph (a) for the purpose of carrving out her intention to procure her own miscarriage, if, before the use of those means, the therapeutic abortion committee for that accredited hospital, by a majority of the members of the committee and at a meeting of the committee at which the case of such female person has been reviewed (c) has by certificate in writing stated that in its opinion the continuation of the pren reviewed, (c) female person would or would be likely to endanger her life such certificate to be given to the qualified medical pre or health, and (d) has caused a copy of therapeutic abortion committee for any hospital to be comprised of "not less 251 (G) requires a each of whom is a qualified medical practitioner" appointed by the board of the three members purpose of determining these matters.

222. See Canada, Report of the Committee on the Operation of the Abortion Law (Ottawa: Supply and Services Canada, 1977) [Badgley, Report].

223. Ibid., 105.

224. Ibid., 124 .

225. Ibid., $277-79$

226. Ibid., 279

227. Ibid., 127. "Almost half of the doctors [surveyed by the Committee] ( $47.7 \%)$ felt that abortion lowered the value of human life. Physicians holding this view worked in virtually every hospital in Canada. When they constituted a majority of the medical staff at eligible hospitals without committees, their views significantly determined a hospital's position on the abortion procedure." 229. Ibid, 201. 
many women reported that they had experienced long delays between the time they first consulted their physician and the time that the abortion was actually performed. ${ }^{230}$ Of particular interest is the report of the national population survey of women conducted by the committee in which women were asked to describe their experiences with abortion. The committee estimated that at a minimum " 49,096 Canadian women between the ages of 15 and 49 years have had illegal abortions." 231 With respect to self-induced abortions, the rate per 1,000 was higher than that reported for other illegal abortions:

For all women in the national population survey, the rate per 1,000 who reported a self-induction was 8.5 and for specific age categories the rates were: none for teenagers between 15 and 17 years; 6.8 per 1,000 between 18 and 23 years; 15.8 per 1,000 between 24 and 29; 5.0 per 1,000 between 30 and 49 years; and 15.5 per 1,000 for women over age 50 years. When these rates are projected on an agespecific basis it is estimated that 55,061 women in Canada had tried or had a self-induction (emphasis added). ${ }^{232}$

This projected figure may or may not include those women who avail themselves of commercial or home-recipe douches for hygenic or contraceptive purposes. In any event, it is a telling figure, because it indicates that despite advances in medicine and changes in the law, however limited they might be, significant numbers of women continue to attempt to induce their own miscarriages.

\section{Conclusion}

This article has reviewed both the historical development of women's criminal liability in Anglo-Canadian criminal law and the emergence and formalization of the therapeutic exception to the abortion prohibition. Throughout, the implications of the law and the active agency of women in the matter of fertility control have been emphasized. It is perhaps paradoxical to insis that "women" must be problematized in this way. However, those of us who work in and around the law tend to be mesmerized by the apparent totality and efficacy of law. And yet, if we confine our investigations to the snakes and ladders of analytical jurisprudence, we will never come close to understanding the real social significance of law. The historically documented struggle of women to control their fertility against the odds of the state, the law, and official medicine should alert us to the potential and significance of medical technology which may facilitate the realization of that longstanding struggle. The criminal law may continue to prohibit it, but it can never prevent it. 